\title{
Observation on AHP Analyzing Constraints for the Development of Enterprise
}

\author{
Annuity in China \\ Mei Fengling \\ College of Economic and Management, Wuhan University
}

\begin{abstract}
The paper uses AHP to make quantitative analysis on the important factors restricting the development of enterprise annuity in China. From the perspective of macro development environment of enterprise annuity, and the enterprise and the employee, the paper makes comprehensive analysis on the factors influencing enterprise annuity in China. Analyzing from the ranking of influencing factors, the paper achieves the most important factor making the enterprise annuity develop slowly, deficient economic strength of enterprises and macro policies.

In resent years, with the promotion and practice of the government, and the active participation of financial institutions, the enterprise annuity has got primary development, but it develops slowly, which is difficult to make supplement on basic endowment insurance, and is unbecoming to enterprise annuity which is the second pillar of social security system in China. According to the previous calculation, from 2011, the increment of enterprise annuity fund has achieved more than 100 billion yuan in China. However, in general, the enterprise annuity is the stage of starting and exploration. Therefore, analyzing the reasons making the enterprise annuity develop slowly and proposing the solutions has great practical significance to promote rapid development of enterprise annuity and fully play the role of it complementing social old-age insurance.
\end{abstract}

Key words: AHP, enterprise annuity, constraints

\section{INTRODUCTION}

In 1980s, AHP was established by T. L.Saaty, the American operational research expert and the professor in the University of Pittsburgh. It is a forceful system analysis and operations research, and it is effective for comprehensive evaluation of multiple factors, criterion and schemes and trend prediction. For the hierarchical structure decision-making analysis problem consisting of scheme layer, factor layer and objective layer, the paper proposes a handling method and process. The most important advantage of AHP is that it can deal with the problem which is combined by qualitative and quantification, can lead the subjective judgment and policy experience of decision-makers into the model to receive quantification. The steps of AHP are as follows.

Firstly, by acknowledging the system, the general objective of the system is determined. The range relating to planning decisions, the measures and policies to be taken, and the criterion, strategies and restriction conditions to realize the objectives is clarified. And the information is widely collected.

Secondly, establishing a multi-level hierarchical structure. According to the difference of the objectives and implementation functions, the system is divided into several levels.

Thirdly, determining the correlation of adjacent level elements in hierarchical structure. By constructing pairwise comparison judgment matrix and mathematical method of matrix operation, the importance ranking, the relative weight, is determined for the elements of the above layer.

Fourthly, computing the synthetic weight of the elements of each layer for system objective for total ranking, for determining the importance of the general objective of each element in the lowest level in hierarchical structure.

Lastly, considering the decisions by analyzing the calculation results. 


\section{Establishment of Index System}

\subsection{Determination of indexes}

The general objective of the paper is to analyze the important factors influencing the development of enterprise annuity in China. According to the feature of problems and the research on the problem, by referring to the literature, the paper makes comprehensive analysis on the enterprise annuity from the perspective of macro development environment of enterprise annuity, the enterprise and the employee. Under the basic elements, the indicators are established.

The first indicator is macro development environment. Macro development environment not only is the basic space of the existence and development of enterprise annuity, but also is the basis for smooth implementation and operation of enterprise annuity. Imperfect macro development environment includes that the substitution rate of the basic old-age insurance is too high, the legislation of enterprise annuity is not perfect, the preferential tax policy is not enough and the capital market is not mature.

The second indicator is enterprise. Enterprise is the important executor of enterprise annuity which plays the key role for the development of enterprise annuity. The insufficiency of enterprise annuity includes that the economic strength of enterprise establishing enterprise annuity is not sufficient, and that the enterprises ignore the stimulation function of enterprise annuity.

The third index is the requirement of the employee. The employees lack of efficient stimulation and guidance, and has no enough acknowledge on enterprise annuity, which makes not trust enterprise annuity. The requirements of most enterprise employees on the real money are greater than the requirement on welfare.

The fourth layer is financial institution. The production chain of enterprise annuity products can be divided into establishment of enterprise annuity plan which is generally completed by annuity trustee, accounting and management of enterprise annuity payment which is charged by accounting manager, investment and management of enterprise annuity which is charged by investment manager and trustee. As the provider for enterprise annuity plan, financial institution plays an important role for the development of enterprise annuity.

\subsection{Establishing index system}

According to the primary analysis on the problem, the included factors are classified, and the relationship of the elements are represented by ligature to compose a hierarchical structure from the top to bottom. The first layer is the total objective layer (A), the general objective of the enterprise annuity develops slowly. The second layer is criterion layer (B), the important aspects for realizing the objective. The third level is sub-criterion layer (c), the detailed indexes. Establishing index system is as follows.

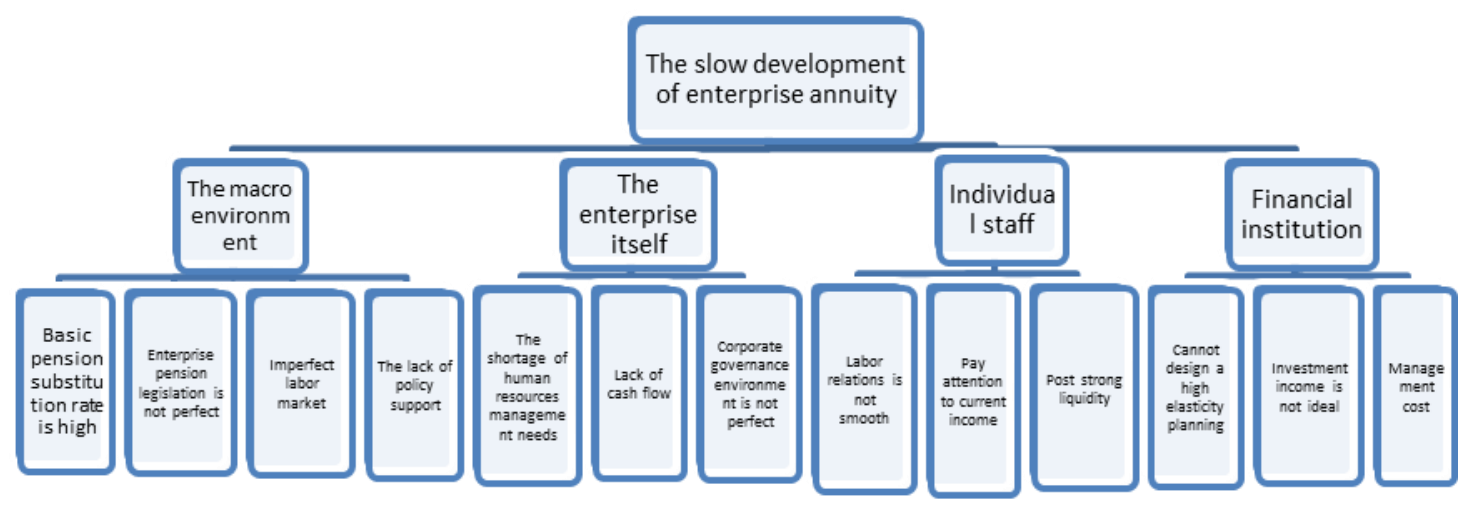

FIG 1. Establishing index system 


\section{Evaluation Results}

From the questionnaire, by combining the opinions of the experts of enterprise annuity and using ratio method ad pairwise comparison, the final evaluation results are achieved. The results determine the relative importance of the factors and assign the scores to establish the judgment matrix of each layer. Then, the weight vector is computed for consistence check.

TABLE 1.Evaluation results

\begin{tabular}{|l|l|c|}
\hline Alternatives & Weight & Ranking \\
\hline The substitution rate of basic old-age insurance is high C1 & 0.0963 & 4 \\
\hline The legislation of enterprise annuity is not perfect C2 & 0.0679 & 7 \\
\hline Labor market is not perfectC3 & 0.0556 & 11 \\
\hline Policy support is deficient C4 & 0.1065 & 3 \\
\hline Human resource management requirements are insufficientC5 & 0.1033 & 1 \\
\hline Economic strength of enterprise is deficientC6 & 0.1180 & 6 \\
\hline Enterprise management is not perfectC7 & 0.0740 & 9 \\
\hline Labor-capital relationship is not perfectC7 & 0.0642 & 5 \\
\hline Emphasizing the current revenue C8 & 0.0838 & 10 \\
\hline Liquidity of jobs is greatC9 & 0.0601 & 12 \\
\hline The plan with great plasticity can't be designedC10 & 0.0529 & 8 \\
\hline Investment profit is not idealC11 & 0.0646 & 12 \\
\hline Management fee is too high C12 & 0.0529 & \\
\hline
\end{tabular}

3.1. Enterprise annuity develops slowly A Judgment matrix consistence proportion: 0.0019 ; Weight for the general objective: 1.0000 ;

\begin{tabular}{|l|c|c|c|c|c|}
\hline $\begin{array}{l}\text { Enterprise annuity develops } \\
\text { slowly A }\end{array}$ & $\begin{array}{c}\text { Macro } \\
\text { environment B1 }\end{array}$ & Enterprise B2 & Employee B3 & $\begin{array}{c}\text { Financial } \\
\text { institution B4 }\end{array}$ & Wi \\
\hline Macro environmentB1 & 1.0000 & 1.2214 & 1.4918 & 1.8221 & 0.3263 \\
\hline Enterprise B2 & 0.8187 & 1.0000 & 1.4918 & 1.8221 & 0.2953 \\
\hline Employee B3 & 0.6703 & 0.6703 & 1.0000 & 1.2214 & 0.2081 \\
\hline Financial institution B4 & 0.5488 & 0.5488 & 0.8187 & 1.0000 & 0.1704 \\
\hline
\end{tabular}


3.2. Macro environmentB1 Judgment matrix consistence proportion: 0.0132; Weight for the general objective: 0.3263 ;

\begin{tabular}{|l|c|c|c|c|c|}
\hline Macro environmentB1 & $\begin{array}{c}\text { The substitution rate } \\
\text { of basic old-age } \\
\text { insurance is high C1 }\end{array}$ & $\begin{array}{c}\text { The legislation of } \\
\text { enterprise annuity } \\
\text { is not perfect C2 }\end{array}$ & $\begin{array}{c}\text { Labor market } \\
\text { is not perfect } \\
\text { C3 }\end{array}$ & $\begin{array}{c}\text { Policy } \\
\text { support is } \\
\text { deficient C4 }\end{array}$ & Wi \\
\hline $\begin{array}{l}\text { The substitution rate of basic } \\
\text { old-age insurance is high C1 }\end{array}$ & 1.0000 & 1.8221 & 1.4918 & 0.8187 & 0.2953 \\
\hline $\begin{array}{l}\text { The legislation of enterprise } \\
\text { annuity is not perfect C2 }\end{array}$ & 0.5488 & 1.0000 & 1.4918 & 0.6703 & 0.2081 \\
\hline Labor market is not perfect C3 & 0.6703 & 0.6703 & 1.0000 & 0.5488 & 0.1704 \\
\hline Policy support is deficient C4 & 1.2214 & 1.4918 & 1.8221 & 1.0000 & 0.3263 \\
\hline
\end{tabular}

3.3. Enterprise B2 Judgment matrix consistence proportion: 0.0043; Weight for the general objective: 0.2953 ;

\begin{tabular}{|l|c|c|c|c|}
\hline Enterprise B2 & $\begin{array}{c}\text { Human resource } \\
\text { management requirements } \\
\text { are insufficient C5 }\end{array}$ & $\begin{array}{c}\text { Cash flow is } \\
\text { deficient C6 }\end{array}$ & $\begin{array}{c}\text { Enterprise management } \\
\text { environment is } \\
\text { imperfect C7 }\end{array}$ & Wi \\
\hline $\begin{array}{l}\text { Human resource management } \\
\text { requirements are insufficient C5 }\end{array}$ & 1.0000 & 0.8187 & 1.4918 & 0.3498 \\
\hline $\begin{array}{l}\text { Economic strength is deficient C6 } \\
\text { Enterprise } \\
\text { environment is imperfect C7 }\end{array}$ & 1.2214 & 1.0000 & 1.4918 & 0.3996 \\
\hline
\end{tabular}

3.4. Employee B3 Judgment matrix consistence proportion: 0.0043; Weight for the general objective: 0.2081 ;

\begin{tabular}{|l|c|c|c|c|}
\hline Employee B3 & $\begin{array}{c}\text { Labor-capital } \\
\text { relationship is not } \\
\text { perfect C7 }\end{array}$ & $\begin{array}{c}\text { Emphasizing the } \\
\text { current revenue C8 }\end{array}$ & $\begin{array}{c}\text { Liquidity of jobs is great } \\
\text { C9 }\end{array}$ & Wi \\
\hline $\begin{array}{l}\text { Labor-capital } \\
\text { relationship is not } \\
\text { perfect C7 }\end{array}$ & 1.0000 & 0.8187 & 1.0000 & 0.3085 \\
\hline $\begin{array}{l}\text { Emphasizing the current } \\
\text { revenueC8 }\end{array}$ & 1.2214 & 1.0000 & 1.4918 & 0.4028 \\
\hline $\begin{array}{l}\text { Liquidity of jobs is } \\
\text { great C9 }\end{array}$ & 1.0000 & 0.6703 & 1.0000 & 0.2886 \\
\hline
\end{tabular}


3.5. Financial institution B4 Judgment matrix consistence proportion: 0.0386; Weight for the general objective: 0.1704 ;

\begin{tabular}{|l|c|c|c|c|}
\hline Financial institution B4 & $\begin{array}{c}\text { The plan with great } \\
\text { plasticity can't be } \\
\text { designed C10 }\end{array}$ & $\begin{array}{c}\text { Investment profit is not } \\
\text { ideal C11 }\end{array}$ & $\begin{array}{c}\text { Management fee is } \\
\text { too highC12 }\end{array}$ & Wi \\
\hline $\begin{array}{l}\text { The plan with great } \\
\text { plasticity can't be } \\
\text { designed C10 }\end{array}$ & 1.0000 & 0.6703 & 1.2214 & 0.3104 \\
$\begin{array}{l}\text { Investment profit is not } \\
\text { ideal C11 }\end{array}$ & 1.4918 & 1.0000 & 1.0000 & 0.3792 \\
\hline $\begin{array}{l}\text { Management fee is too } \\
\text { high C12 }\end{array}$ & 0.8187 & 1.0000 & 1.0000 & 0.3104 \\
\hline
\end{tabular}

\section{Explanation of evaluation results}

From the comprehensive ranking of influencing factors, the most important factor making enterprise annuity develop slowly is that the economic strength of enterprise is deficient. The essence of enterprise annuity is the promotion of the salary of the labors. The wage takes the way of delay in payment. The establishment of enterprise annuity needs to be based on sufficient cash flow and great profit. According to the production decision of enterprises, the enterprises should determine the wage according to the price produced by the labor. The establishment of enterprise annuity actually improves the wage of the employee. Under the condition that the marginal output of the employee has no change, there is no doubt that it is not appropriate for the optimal decision of the enterprises. Therefore, the economic strength of enterprise not only is the first important factor determining the requirement of enterprise annuity, but also is an endogenous factor.

\section{CONCLUSIONS}

The second factor influencing the ranking of enterprise annuity requirement is that the macro policy support is deficient. The essence of the old-age pension is a quasi public product, and enterprise annuity is a quasi public product, which must needs the support of policy.

\section{Reference:}

[1]. Feldstein , Martin , 1974 ,"Social Security , Induced Retirement and Aggregate Capital Accumulation", Journal of Political Economy 82 , no. 5 , pp. $75-95$.

[2]. Feldstein , Martin , 1998 ,"Introduction”, In Privatizing Social Security, edited by Martin Feldstein, The University of Chicago Press.

[3]. Kotlikoff, Laurence J , 1998a ,"The A - KModel Its Past, Present and Future", NBER Working Paper 6684.

[4]. Kotlikoff, Laurence J ., 1998b ,"Simulating the Privatization of Social Security in General Equilibrium", In Privatizing Social Security, edited

[5]. by Martin Feldstein , The University of Chicago Press.

[6]. Malvar, Regina Villela , 1999 "'Three Essays on Social Insurance in Brazil", $\mathrm{PhD}$ Dissertation, Boston University.

[7]. Samuelson , Paul A. , 1958 ,"An Exact Consumption2Loan Model of Interest with or without the Social Contrivance of Money", Journal of Political Economy 66, pp. 467 -482. 